\title{
Using critical and post-critical pedagogies to pick at the seams of patriarchy from 'the inside'
}

\author{
Sherilyn Lennon*
}

Griffith Institute of Educational Research, Griffith University, Brisbane, Australia

\begin{abstract}
This article explores the use of critical and post-critical pedagogies in a rural Australian high school for the purposes of unsettling life-limiting gender beliefs and practices. The paper problematises two examples whereby sitespecific knowledges, curriculum dictates, media texts, and critical pedagogies were enmeshed to create politically charged spaces for re-seeing, re-thinking and re-doing gender. The first example involves a unit of work in which students were required to critically analyse and evaluate a well-known Australian documentary film for the particular version of hypermasculinity that it was valorising. The second example involves the collaborative critiquing of a well-known local text. At the conclusion of the paper I turn a critically reflexive eye upon myself as a way of considering the ethics and issues for educators of challenging power asymmetries from 'the inside'. It is at this point that I discover it is possibly I who have been disrupted most of all.
\end{abstract}

Keywords: critical and post-critical pedagogies; rural; gender; hegemonic masculinity; media literacies

\section{Exploring the links between gender, violence and rurality}

There is significant evidence to suggest that a disproportionately high number of victims of gender-based violence in Australia are from communities that are rural and/or remote (see Dillon, Hussain, \& Loxton, 2015). The links between gender, violence and rurality first became apparent to me when conducting a five-year study into boys' schooling disengagement in a small western Queensland rural community that I had called home for three decades. In Wheatville ${ }^{1}$ I found evidence of hegemonic masculinity manifesting as misogyny, homophobia, physical violence, sexual assault, intimidation, harassment, financial and civic control, exclusionary practices, packing, predation, and a sense of white male entitlement (see Lennon, 2015). In one memorable interview a woman told me of her experience of being sexually assaulted one night after two members of the local rugby club broke into her home. After the assault she felt that she was not in a position to press charges because her attacker was from 'such a well-to-do family in town' (p. 141). In another interview a young female teacher recounted her story of the night a group of intoxicated Year 12 boys stood outside her teachers' accommodation demanding that she come outside because 'we want to fuck you' (p. 103). In yet another incident a health worker told me of a group of high school boys who had filmed, and then circulated, footage of an explicit sexual encounter between themselves and a 16 year-

\footnotetext{
${ }^{*}$ Email: s.lennon@griffith.edu.au
} 
old girl. In the aftermath of the incident, when parents and authorities had become involved, the parents allegedly excused their sons' behaviour with the defence, 'Well what do you expect? Boys will be boys ... and she was a female from, well, not the most desirable social class ... therefore it really didn't matter' (p. 138).

One of the things that I found most troubling about stories such as these was how complicit many of us who lived in the community were in unwittingly sanctioning hierarchical gender regimes and practices that led to the subjugation of females - or the feminine-while endorsing a sense of white male entitlement. This complicity took many forms including excusing male harassment as harmless or a joke, normalising the predation and/or objectifying of females and conflating biological sex with gender ('Boys will be boys'). Cultural myopia had allowed hypermasculine beliefs and practices to seed and take root to such an extent that they had become largely invisible. The consequences of this invisibility were limiting for all of us who lived here.

\section{What is and what to do?}

One particularly toxic representation of local gender roles and relationships could be found in an image marketing an annual social event to the community's youth (see Figure 1 below). Using an only joking motif the image depicted a male emu ('The Emus' was the name of the local rugby club) holding a can of beer while standing aggressively atop a bewildered looking female emu. Emblazoned above the two birds were the words 'The plucked duck'. As part of my extended study I wrote an open letter to the Wheatville newspaper asking if it was 'just me or does anybody else find the logo being used by the committee to advertise their annual event offensive?' (Lennon, 2015, p. 155). In the letter I suggested that the image worked to condone practices associated with gender violence and female subjugation. This triggered an ongoing whole of community debate (at times quite hostile) that played out in the local newspaper, streets, community gatherings and homes of Wheatville over many months. One of the more surprising findings from my action was how many people had 'never noticed it [the image] until Sherilyn pointed it out' (p. 160).

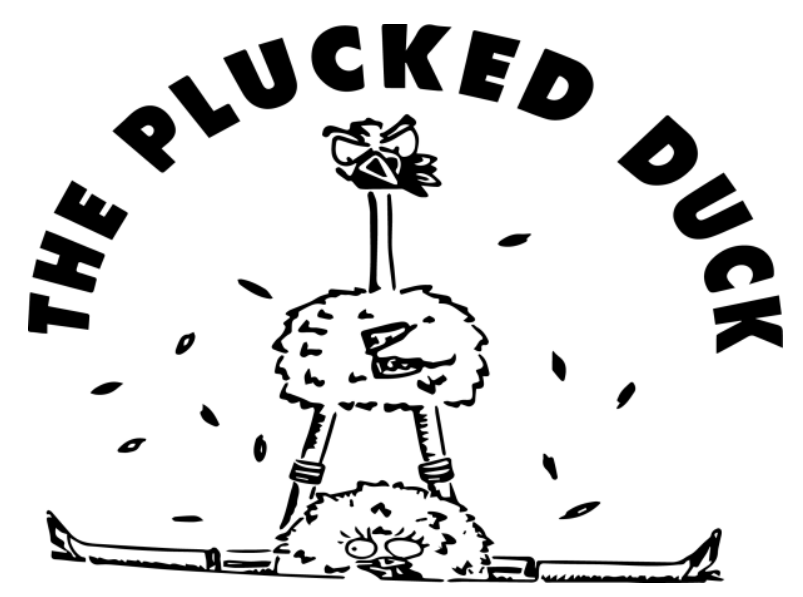

Figure 1 A particularly troubling and well-known local image 
I have not been alone in identifying links between rurality, hypermasculinity and gender violence. Research conducted in regional Australia (see Alloway, Gilbert, Gilbert, \& Muspratt, 2004; Keddie, 2007) gives a disturbing insight into being a girl in some rural communities. Practices relating to domestic violence, negative labelling, and systematic subordination can significantly impact on girls' identities and performances in these places. Here being female becomes associated with 'vulnerablility, sexual objectification and passivity'; being male with 'predatory behaviours, power over girls and women, and sexual desire' (Keddie \& Mills, 2007, p. 34). A combination of geographic isolation from service and health providers, beliefs and practices steeped in heteropatriarchy, lower levels of education and income and a reluctance on the part of the victims to speak up have been credited with perpetuating increased cycles of violence for females living in rural and remote communities (Khalifeh, Hargreaves, Howard, \& Birdthistle, 2013; Wendt, 2009).

While my extended study documented my activist work unsettling hegemonic masculinity with a whole of community focus (see Lennon, 2015), this article sets out to examine the use of critical and post-critical pedagogies to do likewise in the community's Senior English classrooms. It moves back and forth between documenting and then problematising pedagogical approaches that were used to disclose and disrupt practices steeped in hypermasculinity and a sense of white male entitlement. The reflexive loop that is created invites ontological and ethical questions around the possibilities and problematics for educators of working from 'the inside' to destabilise power asymmetries. The paper also touches on issues relating to the sustainability of such approaches.

\section{How the local works to inform gender and schooling performances}

The rural township of Wheatville was located 400 kilometres west of the State's capital city. Here it was surrounded by some of the most fertile and sought after agricultural land in Australia. Fundamental to my understanding of self over the previous three decades had been my connection to this place and its people. It was a place that had come to shape and reshape me just as I, in turn, had shaped and reshaped it. For the purpose of this article I will be using Pini, Moletsane and Mills' (2014) definition of the rural as a space that is 'socially constructed, hybrid, imagined, relational, heterogeneous, dynamic and contested' (p. 455).

In 2000, I was asked by the local high school Principal to research and report on the particularities of students' literacy performances in Wheatville. I began by methodically examining students' academic and behavioural results, and subject area choices. It did not take long to notice a correlation between students' schooling performances and local gender performances. Over the next 13 years, longitudinal data I collected and collated consistently indicated that girls as a cohort outperformed boys in nearly all subject areas and across all year levels. Data also indicated that girls were generally twice as likely as boys to choose subjects enabling direct tertiary entrance upon graduating from high school, with boys, on average, twice as likely as girls to be unemployed in the year following graduation. Although a cursory inspection of these data might appear to position boys as disadvantaged, data can be both misleading and polarising. Destination data collected during the period of my doctoral research showed that unemployment figures for graduating students were relatively low $(<7 \%)$ as was university uptake $(<12 \%)$. The majority of students graduating from Wheatville High found work $(>80 \%)$ within the town or on its 
surrounding farms. Boys were $80-100 \%$ more likely than girls to secure an apprenticeship with girls 80-100\% more likely than boys to secure a traineeship. These clearly gendered post-school trajectories brought with them issues of financial and social inequality. Apprenticeships were considered by many in the community as having more status than traineeships. One of the reasons for this was that they were financially more rewarding - particularly over an extended period of time. What had started out for me as a routine school literacy audit ultimately became a watershed moment in my personal and professional life as I came to understand the links between boys' schooling performances, local gender beliefs and practices, and the economic, social and physical subjugation of females in the community (see Henderson \& Lennon, 2014; Lennon, 2009; 2015).

If cycles of female oppression, masculine hegemony and boys' schooling underperformances are to be interrupted, then making transparent and collaboratively problematising local gender beliefs and practices might be useful starting points. Davies (2005) suggests that educators catch texts in the act of constituting and perpetuating discourses fuelled by hegemonic masculinity with their students in order to lay the foundations for this to happen. In adopting such thinking to foreground the complex, constructed and performative nature of gender with my students, I hoped to be able to pick at the seams of patriarchy and its ugly cousins, hegemonic masculinity and phallocentrism. ${ }^{2}$ To this end I set about planning a documentary film unit that had the potential to encourage a re-seeing, re-thinking and re-doing of generationally entrenched gender constructs and performances. Charteris (2016) claims that, 'discursive reinscription is intrinsic to the notion of performative resignification' ( $p$. 192). If gender performances in Wheatville were to be resignified, then using critical pedagogy to catch texts in the act of peddling discourses valorising hypermasculinity and white male entitlement might just be the trick to get things moving.

\section{An analogy for the usefulness of critical pedagogy}

One Christmas a few years back I was given a set of bird-watching binoculars as a present from my somewhat eccentric brother-in-law. At the time I must confess to having been secretly disappointed. I was in my mid-40s, had never shown an interest in 'twitching' and did not know my pigeons from my plovers. Why would I want to stalk birds? However, as a gesture of appreciation to the present-giver — an avid bird watcher himself - I feigned enthusiasm for the gift and took the binoculars, and an old bird watching manual found wedged between Orwell and Shakespeare on the bookshelf, and headed into 'the field' - the field being thousands of acres of western Queensland sheep, farming and cattle country. I will never forget that precise moment when, overcome with awe and wonder, I began to re-see my world anew; a world that I had lived in for over 20 years. Here right under my nose all that time had been redwinged parrots, spoonbills, Nankeen night herons, colonies of darters and cormorants, pale-headed rosellas, wedge-tailed eagles, impossibly delicate fairy wrens, honeyeaters, magpie geese, plum-headed finches and that most exquisitely elegant of all Australian birds - the dancing brolga. Here they had been and I had never noticed them. For all intents and purposes they had not existed; they had been invisible to me. Needless to say, from this moment on I was hooked. I would never again be able to step outside my farmhouse door without noticing the staccato movements of the restless fly catcher leaping from cedar branch to pool fence as it busied itself snapping greedily at dragonflies or the cat-like mewing of the western bowerbird perfectly imitating the call of its mortal enemy. Quite literally, I had been given a new set of 
lenses - a different framework - through which to see, think about and interact with my world(s). The binoculars had helped to transform my thinking, doing and being. They had achieved this by making visible what could never again be invisible. I draw on this personal experience as an analogy to describe what I believe to be the point and power of critical pedagogy. In re-seeing my world anew the Nankeen night heron had come into being and I had been re-born to re-see, re-think and re-act differently within a familiar world that had become unfamiliar. A few years later, when my neighbour burnt out acres of waterbird breeding grounds in one devastatingly destructive act (which he referred to as 'tidying up the creek bank'), I was the first and loudest to protest. It is this same passion and sense of ur/agency that I sought to inspire in my students as I set about making visible the implications for all of the ways in which many of us were choosing to construct and conduct our gendered lives.

The capacity to make visible what has been invisible for the purposes of transformative thinking, social action, and self-transcendence is a central principle of critical pedagogy (see Freire, 2000; Giroux, 1983, 2007, 2015). In advocating for classroom spaces that are democratic but uncomfortable, productive but unpredictable and supportive but risky, critical pedagogues seek to challenge and transform the status quo by positioning classrooms as political and their occupants as agentic. Giroux (2015) encourages educators using such approaches to build connections between the classroom and students' lifeworlds:

Any viable approach to critical pedagogy suggests taking seriously those maps of meaning, affective investments and sedimented desires that enable students to connect their own lives and everyday experiences to what they learn. (p. 19)

\section{Employing critical pedagogy to unsettle local hegemonies}

If I was to use my classroom for exposing and unsettling local gender regimes and their associated discursive and material performances, I needed to open up spaces where the students and I could question and rethink our understandings of what it meant to do gender. Creating such spaces would require a strategic combination of tasks, pedagogies and resources. I was extremely fortunate in that the teaching colleague with whom I shared the two Senior English classes at the school was as keen as I to trouble local manifestations of gender. Anne's extended period of time in the community meant that she too could identify the ways in which certain beliefs and practices were working to curtail many students' schooling performances and lives. After much discussion and planning, we eventually designed a unit of work that would problematise the version of hegemonic masculinity being lauded by a wellknown Australian documentary film. We understood films as 'common tool(s) for understanding discursive representations of gender and gender relations' (Nairn \& Wyn, 2015, p. 823) and wanted to apply this knowledge in our classrooms as the basis for a re-seeing, re-thinking and re-signifying of local gender performances. We merged our risky and political intentions with the Queensland Senior English syllabus (2010) goal requiring that students 'be empowered as purposeful, creative and critical language users who understand how texts can convey and transform personal cultural perspectives' (p. 1).

The film we chose documents the lives of a group of surfing brothers living in the Sydney northern beaches suburb of Maroubra. The Bra Boys (2007), narrated by

Russell Crowe and directed by one of the brothers, normalises a version of hypermasculinity reifying gang violence, anti-authoritarianism, binge drinking, 
territorialism and high-risk behaviour for males. The film juxtaposes visceral images of waves crashing onto rocks with the antics of an all-male surfing gang. It intercuts footage of the Bra Boys executing daring board manoeuvres and involved in drunken brawls, with footage of them being interviewed about the origins and practices of their gang by a sympathetic interviewee. The brothers are portrayed in the documentary as uneducated but thoughtful, fiercely loyal to each other, and deeply moved by the death of their mother. The images of the unpredictable and untamed ocean are represented as analogous to the lives of the surfing gang - at times brutal and harsh, at others loving and calm. These filmic techniques are used to position audiences to respond favourably to the version of masculinity being portrayed in the film. Drawing on the tenets of critical pedagogy, our students were asked to view the film and then respond to the following task:

The Bra Boys documentary claims to 'produce a heartfelt and exhilarating tale' about a group of Australian brothers and their surfing mates who have survived and thrived against the odds ... You are to write a feature article which challenges the versions of masculinity being valorised by Sunny Abberton in his documentary film, The Bra Boys. Your article should persuade viewers that there are alternative ways of reading the film than that intended by the film maker.

In preparing students for this task my colleague and I set about making visible and unsettling many of the film's carefully crafted messages. Merging critical pedagogies with media literacies we problematised constructions of the Bra Boys as a tight-knit family unit being unfairly targeted by police. Also problematised were notions of the Bra Boys as community leaders; the sanctioning of tribalism and violence if it is to 'protect your turf'; and the authorising of high-risk male behaviour using biologically deterministic catchcries such as 'Boys will be boys'.

We used a five metre long continuum, drawn on butcher's paper and attached to a wall running the full length of the classroom, to capture students' shifting and evolving thinking around the film's subjects. At one end of the continuum was written the word 'Heroes': At the other, 'Zeroes'. Our thinking was that a continuum would allow students to take up multiple positions, thus reinforcing the concept of knowledge as problematic. Students were asked to write their names on post-it notes and position these notes along the continuum at a point which they felt most accurately described the brothers in the film. They were informed that their stances would need to be justified. As anticipated, after the initial viewing of the film, the majority of students positioned their post-it notes around the 'Heroes' end of the continuum. This reinforced for me what my larger study had already unearthed: that gender beliefs and practices sanctioning and celebrating hypermasculinity were firmly entrenched in Wheatville.

Over the next few weeks we identified and evaluated varying filmic techniques being used in the documentary to position viewers to respond empathetically to the Bra Boys. We played and replayed scenes, sometimes with the sound turned off, sometimes with the visuals blacked out, and sometimes after developing further knowledge about the Bra Boys with students-knowledge that was not available in the documentary. This included media releases revealing that members of the Bra Boys' family had been arrested for numerous acts of random violence, tax avoidance, and drug trafficking. Through an interweaving of different sources of evidence, knowledge, interrelated texts and critical questioning, students were encouraged to consider alternative readings of the film and its subjects. Each week we would ask students to reposition themselves along the continuum. If they had shifted their 
thinking, they would be asked to explain why. Over the course of the six-week unit, the clusters of yellow post-it notes gradually and inexorably moved from the 'Heroes' end of the continuum to the 'Zeroes' end of the continuum. A year later, I contacted Anne as part of another research project I was conducting, and asked how the unit was being received in its second rollout. (I had left the school 12 months earlier to pursue an academic career.) Anne explained:

\footnotetext{
The students were so adamantly pro-Bra Boys, even after viewing the doco and were initially quite defensive when we challenged their views. However, one of the biggest breakthrough moments came when we analysed the Bra Boys' attitudes to family. Through the doco the Bra Boys frequently mentioned how important family was to them but when we asked them, 'Well, where were they when Ma was dying? Where were they when Jai was in court facing murder charges? Where was their youngest brother, Dakota?', they could only answer, 'Surfing' or 'We don't know'. When we revealed that after the doco was made, Jai burned the Bra Boys 'brotherhood' tattoo from his arm due to a falling out between the brothers over financial remunerations from the film, they were visibly shocked and finally saw the hypocrisy. One of them actually stated, 'Well, Miss, they are just walking contradictions aren't they?' When asked who agreed, every student except one put their hand up. This was a significant shift in their thinking ...
}

Anne's obvious enthusiasm for the transformative potential of the unit is captured in the following:

\begin{abstract}
It was amazing - and really rewarding - to watch them [the students] shifting their beliefs and opinions about what to aspire to. I mean, at the beginning of the unit they all wanted to be a Bra Boy - or to be their girlfriends, but by the end of the unit they were seeing them as pretty uninspiring and unsavoury characters ... Many of the students were quite open about expressing how their views ... about ... gender ... had changed and that that was going to make them change what they did from now on. It was really rewarding to see those light bulb moments going off in their heads - to see them actually make those changes in their thinking and to know that this had the potential to change the choices they would make for the rest of their lives and to know that you were an important part of all of that.
\end{abstract}

When reading students' responses to the set task, it was apparent that most could identify practices associated with hypermasculinity and critique these for the limitations that they placed on lives. However, rather than celebrating our successes in transforming students' thinking, something was troubling me.

\title{
Being reflexive in a post-critical sort of way
}

Critical pedagogy has been critiqued by scholars on a number of key grounds linked to its origins in emancipatory and critical thought. These include that it is too decontextualised, biased, uncharitable, inflammatory and guilty itself of reproducing hegemonic structures (see Billig, 1991; Gottschall, 2014; Lather, 1991; Luke, 1992; Mayes, 2010). Ellsworth (1989) queries the ethics of educators using the public purse to further their own political agendas. Hayes (2015) questions the authenticity of critical pedagogical practices: 'Since everyone in the classroom knows that the aim is to expose prejudice, there is an urgent need to find a prejudice to expose' (p. 4). Such criticisms work to position critical pedagogues as covert paternalistic oppressors backed by the forces of rationalism and reason ruling over an un/less-knowing constituency against the enemies of commonsense, inequity and injustice.

Hayes (2015) calls for a form of non-critical pedagogy as a way of counterbalancing critical pedagogy's predilections towards co-opting students' thinking and creating binaries out of the oppressed and their oppressors. She 
recommends juxtaposing stories of inequity with those representative of more just alternatives. In this way, instead of tearing down hegemonic structures, educators can work to redesign and/or reshape them, using questions such as 'What do you see?' followed by 'How do you feel about what you see?' (p. 9). Her approach encourages a 'thickness of beliefs' rather than the 'thinness' (p. 6) that can result from pursuing pre-determined and oftentimes polarising agendas. In manifesting post-critical pedagogical approaches in the classroom, questions can be interlaced with new evidence/knowledge/interrelated texts to create generative spaces of ongoing and evolving 'critical-dialectical discourse' (Mezirow, 2003, p. 61). This enables the teacher to take her students (and herself) on a critically reflective and reflexive discovery tour that is not pre-booked and potentially never-ending.

Over two decades ago, Lather (1991) was encouraging a re-envisioning of critical theory within a post-modern framework. She claimed that all knowledge, including the teacher's, should be viewed as fluid, contestable, irreducible and evolving. This thinking frees educators from having to make sense of knowledge and gives birth to multiple readings and multiphrenic beings who are forever being re-inscribed through a re-seeing, re-thinking and re-acting with, in, and through a likewise always shifting and evolving world.

When applying this post-modern framework to our teaching of The Bra Boys film unit, I couldn't help but question some of the approaches that Anne and I had used and wonder if we could have done better. Should we have used an alternative film that was representative of more diverse gender roles and performances? Had we been complicit in reproducing critical hegemony by overriding our students' thinking and reifying our own? The continuum, whilst seemingly offering a multitude of choices, marshalled students between two tightly controlled and regulated end points. Did we genuinely create a shift in thinking or had our students simply been playing the game of critical literacy as formulaic orthodoxy within tightly controlled, teacher-regulated parameters (see Davies \& Hunt, 1994; Keddie, 2008; McLaren, 1998; Ryan, 2007)? Was it ethical of us to set about destabilising our students' gendered worlds? Roberts (2014) argues that, '[i]f the research is not advancing an understanding of the rural, for the rural, it may be just enacting symbolic violence against the places it purports to represent by inadvertently ... constructing them as deviant' (p. 135). Were Anne and I guilty of this? Were our actions and political intent justifiable or by intervening did we perpetuate a new form of violence on our community?

As I was mulling over these questions, out of the blue, I received an email from Anne. (We had not spoken for many months.) Her words worked to reassure me that our efforts to make visible and disrupt life-limiting gender beliefs and practices in Wheatville's English classrooms was ongoing and justifiable. They also helped to provide further clarity around how educators might shift from using critical pedagogies to post-critical ones. In describing a Year 11 English class she had recently taught, Anne demonstrated how she had been able to unsettle thinking around local gender constructs while remaining respectful to the diverse and shifting views of her students. Rather than using a documentary film set elsewhere in Australia, she had made use of a well known local text, the logo, with data that I had collected and collated during my earlier study (see Lennon, 2015):

It was Yr 11 English and we'd been doing some crit lit stuff. I'd shown them some of the newspaper images that you'd collated for your study and we had some interesting

discussions.... I then put the following statement on the board- 'Wheatville is a sexist community' - and asked them to do a 'thumbs up, thumbs down, thumbs sideways' response. Nearly all of them responded with a thumb sideways or thumbs down. I asked them how the 
statement made them feel. Many got quite angry that I would suggest something like that. I then worked through some of the...school data you'd collated and we critically analysed them....They started to get very engaged and we had some amazing discussions. One of the boys made the comment that 'a lot of the machoistic, racist, homophobic and sexist attitudes revealed in these images reflect the fact that we, as a community, are anti-intellectual and that boys don't value education, therefore, their views will never change and our community will continue to perpetuate these attitudes!' (He got a round of applause.) Interestingly, they all agreed that boys, in general, did not value education, it wasn't cool to do well at school in our community and that it was especially hard for boys who did want to do well to succeed/be accepted socially at school here. We finished with the plucked duck image. OMG! I wish you had been there. I put it up and asked them what it was. They all knew straight away. I asked them what it was showing. They said, 'It's just the logo Miss.' I said, 'Yes, but what is it really showing? Look again.' I gave them some thinking time and then you could honestly see the lights go on. The expressions on their faces ranged from shock to embarrassment to laughter. They started to say things like, 'OMG Miss, it looks like that male emu has just raped the female.' 'Look at the expression on his face. He looks so proud of himself. She looks shocked ... like she's exhausted. Look at the way he's standing over her. How aggressive is that. That's terrible. We've never noticed that before. That's shocking. I can't believe that's what it's showing'. I then asked them what this image implied. They said things like, 'That it's OK to be sexually aggressive to women. That women have to just submit to men. That this sort of aggressive sexual activity is condoned. That it's ok to treat women like that in our community. That that's all girls are for-to have sex with. They should just look pretty, support the men and 'be available' for men. It was amazing. They got very upset and were genuinely shocked. We debriefed a little and then I asked them again, 'So is Wheatville a sexist community?' We repeated the thumbs up activity and they all put their thumbs up, including the boys. (Anne, personal correspondence, April, 14, 2016)

After reading her words, one thing had become abundantly clear. If educators using critical and post-critical pedagogies want to maximise the impact of their work with students, they would do well to build explicit links between the curriculum, local texts, local stories, local practices, and local power asymmetries.

\section{Concluding comments}

In writing this article to plumb the usefulness of critical pedagogy as a tool for transforming students' thinking around issues of gender in an isolated rural community, I have finished by generating more questions than answers. This is perhaps symptomatic of having crossed the paradigmatic floor from the use of critical pedagogies to post-critical ones. In reflecting on the film unit that Anne and I designed, I can recognise that we did do some things well. We opened up dialogic spaces around hegemonic masculinity with our students. We valued and encouraged students' divergent ideas and thinking on the topic - albeit within pre-ordained parameters - and we built links between a film text's representations of masculinity and those of our local community. However, there are also things that I believe could have been done better. These open up important questions for educators using critical pedagogies for transformative purposes: Do students play the critically literate game with teachers telling us what we want to hear? If so, can the use of local texts help to maximise engagement and thus avoid game-playing? In destabilising local beliefs, practices and power hierarchies, do we violate our students' lives and the system's trust in us as teachers? Is the alternative - to ignore hegemonic structures that are limiting students' schooling performances and lives - worse?

In designing and implementing curricula aimed at enacting social and cultural reforms, educators tread tenuous tightropes between compliance with externally 
imposed curriculum demands, the needs of their students, and ethical considerations. The approaches outlined in this article have hinted at some of the ways that this might be done. By merging top-down systemic priorities with local knowledges and postcritical pedagogies, it would appear that it is possible to impact on students' thinking and practices and, as a consequence, their lives. Of the two classroom examples presented here - the Year 12 film study and Anne's lesson problematising the logoit is Anne's lesson that has more fully embraced the nuances of post-critical pedagogies capable of leading to 'performative resignification' (Charteris, 2016, p. 192). Evidence of this is witnessed in the spontaneous applause erupting from the class after a male students' outspoken recognition of the dangers for the community of valorising hypermasculine and phallocentric ideals. However, both examples worked to forge spaces that were politically charged, variously relatable to students' lifeworlds, engaging and potentially transformative. In doing so they enacted Freire's idea of reading the word (or image) to read the world (see Freire \& Macedo, 1987) and quite possibly changed the lives of some members of one rural community forever.

\section{Notes}

1 Pseudonyms have been used throughout to protect identities

2 A term referring to dominance and power over others through the use of the symbol of the phallus or sexual superiority.

\section{References}

Abberton, S., \& Beattie, S. (Writers), \& Abberton, S., \& De Souza, M. (Directors). (2007). The Bra Boys [Documentary film]. Australia: Bradahood Productions.

Alloway, N., Gilbert, P., Gilbert, R., \& Muspratt, S. (2004). Factors impacting on student aspirations and expectations in regional Australia. James Cook University: Commonwealth of Australia.

Billig, M. (1991). Ideology and opinions: Studies in rhetorical psychology. London: Sage.

Charteris, J. (2016). Envisaging agency as discourse hybridity: a Butlerian analysis of secondary classroom discourses. Discourse: Studies in the Cultural Politics of Education, 37(2), 189-203. doi: 10.1080/01596306.2014.943156

Davies, B. (2005). The subject of post-structuralism: A reply to Alison Jones. In C. Skelton \& B. Francis (Eds.), A feminist critique of education: 15 years of gender education (pp. 96-109). London and New York: Routledge.

Davies, B., \& Hunt, R. (1994). Classroom competencies and marginal positionings. British Journal of Sociology of Education, 15(3), 389-408. doi: 10.1080/0142569940150306

Dillon, G., Hussain, R., \& Loxton, D. (2015). Intimate partner violence in the young cohort of the Australian longitudinal study on women's health: Urban/rural comparison and demographic associations. Advances in Mental Health, 13(1), 18-29. doi: 10.1080/18374905.2015.1039752

Ellsworth, E. (1989). Why doesn't this feel empowering? Working through the repressive myths of critical pedagogy. Harvard Educational Review, 59(3), 297-325. doi: 10.17763/haer.59.3.058342114k266250

Freire, P. (2000). Pedagogy of the oppressed. In A. Freire \& D. Macedo (Eds.), The Paulo Freire reader (pp. 46-79). New York, NY: Continuum International. 
Freire, P., \& Macedo, D. (1987). Literacy: Reading the word and the world. New York, NY: Bergin \& Garvey.

Giroux, H. (1983). Theory and resistance in education: A pedagogy for the opposition. South Hadley, MA: Bergin \& Garvey.

Giroux, H. (2007). Introduction. In P. McLaren \& J. Kincheloe (Eds.), Critical pedagogy: Where are we now? (pp. 1-5). New York, NY: Peter Lang.

Giroux, H. (2015, October 13). The curse of totalitarianism and the challenge of critical pedagogy [blog]. Retrieved from https://philosophersforchange.org/2015/10/13

Gottschall, K. (2014). From the frozen wilderness to the moody sea: Rural space, girlhood and popular pedagogy. Gender and Education, 26(5), 568-583. doi: http://dx.doi.org/10.1080/09540253.2014.944486

Hayes, D. (2015). Against critical thinking pedagogy. Arts and Humanities in Higher Education, 14(4), 318-328. doi: 10.1177/1474022215592248

Henderson, R., \& Lennon, S. (2014). A conversation about research as risky business. In S. White \& M. Corbett (Eds.), Doing educational research in rural settings. Methodological issues, international perspectives and practical solutions (pp. 119-134). New York, NY: Routledge.

Keddie, A. (2007). Games of subversion and sabotage: Issues of power, masculinity, class, rurality and schooling. British Journal of Sociology of Education, 28(2), 181-194. doi: http://dx.doi.org/10.1080/01425690701192596

Keddie, A. (2008). Playing the game: Critical literacy, gender justice and issues of masculinity. Gender and Education, 20(6), 571-583. doi: 10.1080/09540250701829979

Keddie, A., \& Mills, M. (2007). Teaching boys: Developing classroom practices that work. Crows Nest, NSW: Allen \& Unwin.

Khalifeh, H., Hargreaves, J., Howard, L. M., \& Birdthistle, I. (2013). Intimate partner violence and socioeconomic deprivation in England: Findings from a national cross-sectional survey. American Journal of Public Health, 103(3), 462-472. doi: 10.2105/AJPH.2012.300723

Lather, P. (1991). Feminist research in education: Within/Against. Geelong, Victoria: Deakin University.

Lennon, S. (2009). A one year journey in the life of a literacy project officer: Learning about boys and motivating others. Literacy Learning: The Middle Years, 17(2), 46-52. doi: http://search.informit.com.au/documentSummary;dn=811422352909463;res=IELHSS

Lennon, S. (2015). Unsettling research: Using critical praxis and activism to create uncomfortable spaces. New York, NY: Peter Lang.

Luke, C. (1992). Feminist politics in radical pedagogy. In C. Luke, \& J. Gore (Eds.), Feminisms and critical pedagogy (pp. 25-53) New York, NY: Routledge.

Mayes, P. (2010). The discursive construction of identity and power in the critical classroom: Implications for applied critical theories. Discourse \& Society, 21(2), 189-210. doi: 10.1177/0957926509353846

McLaren, P. (1998). Revolutionary pedagogy in post-revolutionary times: Rethinking the political economy of critical education. Educational theory, 48(4), 431-462. doi: 10.1111/j.17415446.1998.00431.x

Mezirow, J. (2003). Transformative learning as discourse. Journal of Transformative Education, 1(1), 58-63. doi: 10.1177/1541344603252172

Nairn, K., \& Wyn, J. (2015). New girlhood and lost boys: Analysing the cultural politics of gender and education through film. Discourse: Studies in the Cultural Politics of Education, 36(6), 821-832. doi: http://dx.doi.org/10.1080/01596306.2014.973372 
Pini, B., Moletsane, R., \& Mills, M. (2014). Education and the global rural: Feminist perspectives. Gender and Education, 26(5), 453-464. doi: http://dx.doi.org/10.1080/09540253.2014.950016 Queensland Government. (2010). English Senior Syllabus 2010. South Brisbane: Queensland Studies Authority.

Roberts, P. (2014) Researching from the standpoint of the rural. In S.White, \& M. Corbett (Eds.). Doing educational research in rural settings. Methodological issues, international perspectives and practical solutions (pp. 135-147). New York, NY: Routledge.

Ryan, M. (2007). Critical pedagogy and youth: Negotiating complex discourse worlds. Pedagogy, Culture \& Society, 15(2), 245-262. doi: http://dx.doi.org/10.1080/14681360701406691

Wendt, S. (2009). Constructions of local culture and impacts on domestic violence in an Australian rural community. Journal of Rural Studies, 25(2), 175-184. doi: http://dx.doi.org/10.1016/j.jrurstud.2008.11.001 